\title{
PARENTING STRESS DAN PARENTING ALLIANCE PADA IBU YANG MENJADI WARGA BINAAN PEMASYARAKATAN
}

\author{
Dhini Andriani, Elmira N. Sumintardja, Muniroh Abdurachman \\ Fakultas Psikologi Universitas Padjadjaran \\ Jl. Raya Bandung Sumedang KM.21 Kabupaten Sumedang, Jawa Barat 45363 \\ Email: dhini.andriani@unpad.ac.id
}

\begin{abstract}
ABSTRAK. Selama berada di lapas Ibu yang menjadi WBP harus berpisah dengan anak mereka dan tidak dapat mengasuh anak secara langsung, serta harus membangun hubungan dengan pengasuh anak mereka. Penelitian ini bertujuan untuk mengetahui bagaimana gambaran parenting stress dan parenting alliance serta korelasi diantara keduanya pada Ibu yang menjadi Warga Binaan Pemasyarakatan (WBP). Pengukuran menggunakan Parenting Stress Index (PSI) dan parenting Alliance Measure (PAM). Total partisipan penelitian adalah 43 ibu yang menjadi WBP. Analisa data menggunakan statistik deskriptif dan korelasi Spearman rho. Ibu yang menjadi WBP memiliki parenting stress yang cenderung rendah. Hal ini berarti meskipun berada di Lapas, para Ibu yang menjadi WBP memiliki sumberdaya yang cukup untuk dapat menjalankan tuntutan sebagai orang tua. Diantara tujuh dimensi pada parenting stress, hanya dimensi depression bernilai tinggi. Hal ini menunjukkan mereka Ibu yang menjadi WBP memiliki perasaan bersalah karena tidak dapat mengasuh anak secara langsung dan tidak merasa puas menjalankan peran sebagai orang tua. Ibu yang menjadi WBP memiliki penilaian yang tinggi terhadap parenting alliance yang dibentuk dengan pengasuh anak. Hal ini berarti mereka merasakan adanya komunikasi dan kerjasama, serta komitmen dari pengasuh anak. Hasil menunjukkan bahwa tidak terdapat hubungan yang signifikan antara parenting stress dan parenting alliance pada Ibu yang menjadi WBP. Saran penelitian selanjutnya adalah tidak hanya mengukur Ibu yang menjadi WBP, tapi juga mengukur parenting alliance pada pengasuh anak, serta bagaimana penyesuaian diri anak terhadap perpisahan dengan ibu karena pemenjaraan.
\end{abstract}

Kata kunci: ibu; warga binaan pemasyarakatan; parenting stress; parenting alliance

\section{PARENTING STRESS AND ALLIANCE ON INCARCERATED MOTHERS}

\begin{abstract}
During incarceration, incarcerated mother had to part with their children and unable to care for children directly, and they have to develop alliance with the child's caregiver. This study aims to describe parenting stress and parenting alliance as well as the correlation between the parenting stress and parenting alliance among incarcerated mothers. Measurement used Parenting Stress Index (PSI) and parenting Alliance Measure (PAM). The total participants were 43 incarcerated mothers. Data analysis uses descriptive statistics and Spearman rho correlations. The results showed that incarcerated mother have tends to be low level of parenting stress. It means that even though they are in prison, incarcerated mothers have sufficient resources to be able to carry out demands as a parent. Among the seven dimensions of parenting stress, only the dimension of depression is of high value. This shows that those incarcerated mothers feel guilty because they cannot take care of their children directly and are not satisfied in carrying out their role as parents. Incarcerated mothers have a high evaluation of the parenting alliance formed with their child caregiver. This means they feel communication and cooperation, as well as the commitment of child parenting. The results showed that there was no significant correlation between parenting stress and parenting alliance among incarcerated mothers. Suggestions for further research are not only measuring incarcerated mothers, but also measuring parenting alliance in child caregivers, as well as how children adjust to separation from mothers due to imprisonment.
\end{abstract}

Keywords: incarcerated mother; parenting stress; parenting alliance

\section{PENDAHULUAN}

Pemenjaraan merupakan salah satu pengalaman paling stres. Griffith dan Steptoe (2000) juga menyebutkan bahwa hubungan interpersonal dengan staf penjara, warga binaan pemasyarakatan (WBP) lainnya, dan tegangnya hubungan dengan teman dan keluarga juga menimbulkan gangguan psikologis. Sejumlah penelitian mengidentifikasi stressor yang dilaporkan oleh WBP. Menurut Griffith dan Steptoe (2000) stresor tersebut terdiri dari beberapa kategori:

1. Hubungan personal: perpisahan dengan pas- angan dan keluarga merupakan salah satu stresor utama selama berada di penjara.

2. Faktor ekonomi: hilangnya pendapatan terkait pemenjaraan dapat menjadi masalah utama bagi narapidana dan keluarga mereka

3. Lingkungan penjara: kurangnya privacy dan keramaian merupakan masalah utama dalam lingkungan penjara.

Berdasarkan analisis data awal mengenai stressor utama pada WBP Wanita di Lembaga Pemasyarakatan (Lapas) Wanita yang dilakukan peneliti, ditemukan bahwa dari 69 partisipan, $97,10 \%$ diantaranya merasa 
bahwa perpisahan dengan keluarga merupakan hal paling berat dan 59,06\% merasa stres karena terpisah dari anak. Hasil analisia data awal ini mirip dengan penelitian sebelumnya yang dilakukan Fadhilah (2013) bahwa Ibu yang menjadi WBP memiliki stres terkait anak.

WBP wanita yang berada di Lapas berada pada rentang usia 20 hingga 60 tahun, yang berarti saat ini mereka berada pada tahap perkembangan untuk berperan sebagai istri dan ibu. Berada di dalam Lapas membuat tugas perkembangan tersebut terganggu. Bagi ibu, salah satu hukuman terberat yang menyertaai pemenjaraan adalah perpisahan dengan anak. Banyak ibu yang menjadi WBP tinggal bersama anak dan merupakan pengasuh utama anak mereka sebelum menjadi WBP (Parke \& Clarke-Stewart, 2002). Stres spesifik yang ditemukan pada wanita yang berada di Lapas adalah perpisahan dengan keluarga, khawatir mengenai anak, kehilangan kontrol terhadap hidup mereka (Fogel, 1993). Perpisahan dengan anak dihubungkan dengan perasaan rasa bersalah, cemas mengenai kesejahteraan anak, dan ketakutan hilangnya ikatan (attachment) dengan anak. Hal ini dapat menjadi alasan mengapa wanita ditemukan lebih merasakan stres emosional di penjara dibandingkan pria (Griffith dan Steptoe, 2000).

Parenting stress adalah suatu kondisi distress yang dialami sebagai hasil dari persepsi tuntutan-tuntutan sebagai orang tua (Deater-Deckard, 2004). Stres terkait kompeten sebagai orang tua berhubungan dengan kecemasan dan gejala depresi (Fogel, 1993; Houck \& Loper, 2002) begitu juga dengan pelanggaran yang dilakukan di lapas (Houck \& Loper, 2002). Penelitian ini lebih membahas parenting stress yang berasal dari atribut orang tua itu sendiri (domain orang tua). Domain orang tua berarti sumber stres dan masalah yang dapat menggangu hubungan orang tua-anak dan berhubungan dengan fungsi orang tua. Karaktersitik orang tua merupakan faktor unik pada orang tua, tapi juga memiliki dampak yang signifikan pada hubungan anak-orang tua. Pada Ibu yang menjadi WBP, domain orang tua adalah bagaimana ini mempersepsi tuntutan dia sebagai orang tua dan sumberdaya yang dimiliki dan mengaitkannya dengan kondisi dirinya saat ini yang berada di Lapas.

Berada di lapas, Ibu yang menjadi WBP tidak dapat mengasuh anak secara langsung. Berdasarkan riset yang dilakukan oleh Momula (2000), ketika seorang ayah harus menjalani masa hukuman di Lapas, 90\% anak mereka akan diasuh oleh ibu mereka, sementara pada Ibu yang menjalani masa hukuman di lapas hanya $28 \%$ yang anaknya diasuh oleh ayah mereka. Anak akan diasuh oleh anggota keluarga lain seperti kakek/nenek anak, atau anggota keluarga lain. Hal ini berarti, Ibu yang berada di Lapas tidak selalu membentuk parenting alliance dengan ayah anak, tapi dengan anggota keluarga lain yang mengasuh anak mereka. Parenting alliance adalah kemampuan orang tua untuk bekerja sama satu sama lain untuk memenuhi kebutuhan anak (Abidin \& Konold, 1999). Penting bagi Ibu yang menjadi WBP membentuk parenting alliance, karena pengasuh anak akan berperan menghubungkan antara Ibu dan anak, seperti menjenguk ke Lapas, menerima telepon, dan menerima atau mengirimkan surat.

Penelitian sebelumnya di US menemukan bahwa parenting stress yang meningkat dan disertai dengan parenting alliance yang rendah dengan pengasuh anak di rumah maka akan meningkatkan gejala depresi serta pelanggaran yang akan berujung pada penyesuaian diri yang buruk (Loper, Carlson, Levitt, \& Scheffel, 2009). Penelitian ini bertujuan untuk melihat hubungan antara parenting stress dan parenting alliance pada ibu yang menjadi WBP dan memberikan gambaran mengenai parenting stress dan parenting alliance pada Ibu yang menjadi WBP di salah satu Lapas Wanita di Indonesia.

\section{METODE}

Rancangan riset yang digunakan adalah desain penelitian survei, metode penelitian survei yang digunakan adalah cross-sectional study. Cross-sectional study adalah satu atau lebih sample diambil dari populasi pada satu waktu. Salah satu fokus cross-sectional design adalah mendeskripsikan karakteristik dari suatu populasi pada waktu tertentu (Shaughnessy et al, 2012). Analisis data yang digunakan adalah deskriptif dan Spearman's rho.

Kuesioner yang digunakan dalam penelitian ini adalah self-administered questionnaire dimana responden mengisi kuesioner yang sudah disiapkan sebelumnya oleh peneliti. Alat ukur yang digunakan dalam penelitian ini adalah sebagai berikut:

- Data demografi: usia, usia anak, pendidikan, jenis pidana, masa hukuman, apakah mengasuh anak saat sebeum masuk lapas, dan siapa pengasuh anak saat ini.

- Parenting Stress Index (PSI) (Abidin, 2012) memiliki reliabilitas sebesar 0,911 . PSI yang digunakan adalah ketujuh subscale parent domain, yaitu competence (delapan item), attachment (lima item), role restriction (enam item), depression (delapan item), spousel parenting partner relationship (enam item), isolation (lima item) dan health (tiga item). PSI telah memiliki versi bahasa Indonesia, dalam penelitian ini terjemahan yang sudah ada direview kembali oleh salah seorang dosen fakultas Psikologi yang sedang menjalani program doktor di Belanda. Versi asli 
berbahasa Inggris dan bahasa Indonesia dibandingkan, kemudian dilakukan revisi. Jumlah item yang digunakan adalah 41 item dari 54 item dalam versi asli PSI. Pilihan jawaban adalah 1-5 (sangat tidak setuju - sangat setuju). Skor minimun adalah 41 dan skor maksimum adalah 125 . Dalam penelitian ini, derajat stres total dibagi dalam empat level: tinggi, cenderung tinggi, cenderung rendah, dan rendah. Masing-masing dimensi juga ditotal dan terbagi dalam empat level. - Parenting Alliance Measure (PAM) (Abidin \& Konold, 1999) memiliki reliabilitas 0,885 . Sebelum digunakan dilakukan translate dan back-translate. Modifikasi dilakukan untuk menyesuaikan dengan tempat penelitian. PAM terdiri dari dimensi komunikasi dan kerjasama dan perasaan dihormati oleh orang tua lain. Jumlah item adalah 20. Pilihan jawaban adalah 1-5 (sangat tidak setuju - sangat setuju). Skor minimun adalah 20 dan skor maksimum adalah 100 . Dalam penelitian ini, derajat parenting alliance dibagi dalam empat level: tinggi, cenderung tinggi, cenderung rendah, dan rendah.

Saat mengisi kuesioner PSI dan PAM partisipan diminta hanya memikirkan satu anak yang paling mereka khawatirkan atau yang paling sering mereka pikirkan. Partisipan menuliskan usia anak tersebut dan menuliskan anak ke berapa dari berapa anak.

Kriteria partisipan dalam penelitian ini adalah minimal berpendidikan SMA dan memiliki anak. Metode sampling yang digunakan adalah convenient. Partisipan diperoleh dengan meminta kepada WBP yang diperbantukan untuk bekerja di blok hunian dengan pengawasan petugas (korve) di Lapas untuk mencarikan WBP yang sesuai dengan kriteria tersebut. Setelah korve memiliki daftar, WBP yang sesuai dengan kriteria dipanggil untuk mengisi kuesioner. Sebelum pengisian kuesioner, WBP mendapatkan penjelasan dari peneliti. Dari sekitar 350 lebih WBP yang ada, WBP yang dipanggil adalah sekitar 50 orang. Namun, tidak semua bersedia mengikuti penelitian dan terdapat juga yang dipanggil namun tidak sesuai dengan kriteria. Misalnya, WBP tersebut telah menikah tapi tidak memiliki anak ataupun WBP yang berpendidikan dibawah SMA. Total partisipan yang mengisi kuesioner dan sesuai kriteria adalah 43 orang. Pengambilan data dilakukan pada Juli-Agustus 2014 di Lembaga Pemasyarakatan Wanita Klas IIA Bandung.

\section{HASIL DAN PEMBAHASAN}

Jumlah partisipan dalam penelitian ini adalah 43 orang dengan rata-rata usia 38,29 tahun. Sebagain besar dari mereka berpendidikan setara SMA. Saat pengambilan data berlangsung setengah dari partisipan berstatus menikah dan sebagian lainnya berstatus janda. Sebagai besar dari mereka melakukan tindak pidana terkait narkoba. Masa hukuman mereka bervariasi dari ringan hingga berat. Hampir semua subjek, yaitu 93\% diantaranya mengasuh anak mereka secara langsung saat mereka belum masuk Lapas. Setelah berada di Lapas, sebagian besar anak dari Ibu yang menjadi WBP diasuh oleh orang lain yang bukan ayah mereka, yaitu sebesar $69.8 \%$ diasuh oleh Kakek atau nenek, anggota keluarga lain, atau panti asuhan (Tabel 1).

Para Ibu yang menjadi WBP memiliki derajat parenting stress yang cenderung rendah. Hal ini berarti para Ibu yang menjadi WBP memiliki sumberdaya yang memadai untuk memenuhi tuntutan sebagai seorang ibu. Pada Table 2, enam dimensi pada parenting stress, yaitu competence, parental attachment, role restriction, spousel parenting partner relationship, isolation, dan health memiliki derajat cenderung rendah. Hanya dimensi depression memiliki derajat cenderung tinggi.

Berdasarkan Tabel 1, terlihat bahawa bahwa hampir semua ibu yang menjadi WBP mengasuh anak mereka secara langsung saat mereka belum masuk Lapas. Selama berada di Lapas, anak diasuh oleh oleh orang lain yang bukan ayah mereka, yaitu sebesar $69.8 \%$ diasuh oleh Kakek atau nenek, anggota keluarga lain, atau panti asuhan. Kondisi ini mirip dengan penelitian sebelumnya bahwa, ketika Ibu yang menjadi WBP hanya $28 \%$ anak diasuh oleh ayah mereka (Mumola, 2000), dan bahwa sebagian besar anak diasuh oleh kakek/nenek (Parke \& Clarke-Stewart, 2002)

Ibu yang menjadi WBP memiliki parenting stress terkait competence yang rendah. Berarti Ibu memiliki keyakinan bahwa dirinya merasa nyaman dan merasa kompeten menjalankan peran pengasuhan. Berada di lapas, Ibu yang menjadi WBP memiliki pengetahuan bagaimana mengatur anak mereka dan mereka tetap dapat membuat keputusan penting untuk anak mereka.

Parental attachment pada parenting stress adalah mengukur keterlibatan intrinsik dalam berperan sebagai orang tua. Dengan derajat yang cenderung rendah pada dimensi ini, dapat dikatakan bahwa Ibu yang menjadi WBP memiliki motivasi untuk memenuhi peran sebagai orang tua. Hasil ini sama dengan penelitian sebelumnya yang menunjukkan bahwa Ibu yang menjadi WBP merasakan bahwa memiliki ikatan (attachment) yang kuat dengan anak mereka dan keyakinan bahwa anak mencintai mereka (Loper et al., 2009). Di Lapas, WBP memiliki hak untuk dikunjungi dan menelpon, pada saat dikunjungi oleh anak dan menelpon anak dapat diasumsikan bahwa para ibu tersebut dapat berinteraksi dengan 
anak secara dekat dan dapat merespon anak secara efektif. Motivasi untuk berperan menjadi seorang ibu terpenuhi saat kunjungan dan saat menelepon anak mereka. Role restriction adalah perasaan orang tua mengenai kebebasan dan identitas pribadi yang terbatas karena menjalani peran sebagai orang tua. Dimensi role restriction menjelaskan mengenai perasaan marah bahwa mengasuh anak mengorbankan peran kehidupan yang lain. Namun, pada Ibu yang menjadi WBP, perasaan bahwa peran orang tua membatasi identitas pribadi mereka tidak dirasakan. Dengan kondisi berada di Lapas, Ibu yang menjadi WBP sudah merasakan keterbatasan sebagai individu secara keseluruhan. Hal tersebut dapat saja menjadikan penilaian pada dimensi role restriction sebagai orang tua tidak terlalu dirasakan oleh Ibu yang menjadi WBP. tergambar dari dimensi spousel parenting partner relationship (SP) yang cenderung rendah. Hal ini didukung dengan dimensi isolation yang juga memiliki derajat cenderung rendah. Isolasi melihat derajat isolasi orang tua dan ketersediaan dukungan sosial. Berdasarkan dua dimensi tersebut, dapat diasumsikan bahwa Ibu yang menjadi WBP memiliki dukungan dari pengasuh anak untuk melakukan perannya sebagai orang tua.

Dimensi health pada parenting stress mengukur dampak tuntutan sebagai orang tua terhadap kesehatan fisik. Derajat yang cenderung rendah pada dimensi ini menunjukkan bahwa Ibu yang menjadi WBP tidak mengalami penurunan kesehatan sebagai akibat dari tuntutan sebagai orang tua.

Dimensi depression menunjukkan status efektif orang tua dan skor pada dimensi ini menunjukkan ter-

Tabel 1: Karakteristik Demografi Partisipan

\begin{tabular}{|c|c|}
\hline Karakteristik Demografi & Rata-rata (standar deviasi) \\
\hline Usia partisipan (tahun) & 38,29 tahun $(7,16)$ \\
\hline Usia anak pertama (tahun) & 10,63 tahun $(5,06)$ \\
\hline & n (\%) \\
\hline $\begin{array}{l}\text { Pendidikan } \\
\qquad \begin{array}{l}\text { SMA } \\
\text { Diploma } \\
\text { Sarjana } \\
\text { Master }\end{array}\end{array}$ & $\begin{array}{l}30(69,8 \%) \\
3(7 \%) \\
9(20,9 \%) \\
1(2,3 \%) \\
\end{array}$ \\
\hline $\begin{array}{l}\text { Status Pernikahan } \\
\qquad \begin{array}{l}\text { Belum menikah } \\
\text { Menikah } \\
\text { Janda }\end{array}\end{array}$ & $\begin{array}{l}1(2,3 \%) \\
21(48,8) \\
21(48,8 \%)\end{array}$ \\
\hline $\begin{array}{l}\text { Tindak Pidana } \\
\qquad \begin{array}{l}\text { Kekerasan (crime with violence) } \\
\text { Bukan Kekerasan (Non-violence) } \\
\text { Narkoba (drugs) }\end{array}\end{array}$ & $\begin{array}{l}3(7 \%) \\
17(39,5 \%) \\
23(53,5 \%)\end{array}$ \\
\hline $\begin{array}{l}\text { Masa Hukuman } \\
\qquad \begin{array}{l}\text { Ringan ( } 6 \text { bulan s/d } 4 \text { tahun) } \\
\text { Sedang ( }>4 \text { tahun s/d } 10 \text { tahun) } \\
\text { Berat ( }>10 \text { tahun) }\end{array}\end{array}$ & $\begin{array}{l}14(32,6 \%) \\
15(34,9 \%) \\
14(32,6 \%)\end{array}$ \\
\hline $\begin{array}{l}\text { Mengasuh anak saat masih di luar } \\
\text { Ya } \\
\text { Tidak } \\
\text { Tidak menjawab } \\
\end{array}$ & $\begin{array}{l}40(93 \%) \\
2(4,7 \%) \\
1(2,3 \%)\end{array}$ \\
\hline $\begin{array}{l}\text { Pengasuh Anak } \\
\text { Ayah } \\
\text { Kakek/ Nenek } \\
\text { Anggota keluarga lainnya } \\
\text { Bukan keluarga }\end{array}$ & $\begin{array}{l}13(30,2 \%) \\
21(48,8 \%) \\
7(16,3 \%) \\
2(4,7 \%)\end{array}$ \\
\hline
\end{tabular}

Ibu yang menjadi WBP memiliki persepsi bahwa mereka mendapatkan dukungan emosional dan fisik dari pasangan atau pengasuh anak mereka. Kondisi ini ganggunya energi dan emosi. Ibu yang menjadi WBP memiliki tingkat cenderung tinggi pada dimensi ini. Skor pada dimensi ini juga mengungkap adanya perasaan ber- 
salah pada orang tua (Cornish et al, 2006; Webster-Stratton, 1988 dalam Abidin, 2012). Depression yang cenderung tinggi ini dapat menunjukkan perasaan bersalah pada Ibu yang menjadi WBP karena harus berpisah dengan anak dan tidak dapat mengasuh secara langsung. Hal ini juga menggambarkan bahwa Ibu yang menjadi WBP tidak puas menjalani perannya sebagai orang tua. Secara umum dimensi depresi menunjukkan bahwa orang tua sulit untuk menggerakkan energi fisik dan psikis yang dibutuhkan untuk memenuhi tanggung jawab sebagai orang tua (Dumas, Gibson, \& Albin, 1989; Pan, Rowe, Singer, \& Snow, 2005 dalam Abidin, 2012). Beberapa pernyataan pada dimensi depression berhubungan dengan rasa bersalah dan perasaan tidak bahagia, tidak untuk menunjukkan depresi secara klinis.

Tabel 2. Level Parenting Stress dan Parenting Alliance pada Ibu yang berada di Lapas

\begin{tabular}{|l|l|l|}
\hline \multicolumn{1}{|c|}{ Variabel } & \multicolumn{1}{|c|}{ Rata-rata (SD) } & \multicolumn{1}{|c|}{ Keterangan } \\
\hline $\begin{array}{l}\text { Parenting Stress } \\
\text { Index }\end{array}$ & $108,48(20,63)$ & $\begin{array}{l}\text { Cenderung } \\
\text { rendah }\end{array}$ \\
\hline Competence & $22.14(5.51)$ & $\begin{array}{l}\text { Cenderung } \\
\text { rendah }\end{array}$ \\
\hline $\begin{array}{l}\text { Parental Attach- } \\
\text { ment }\end{array}$ & $11.09(3.26)$ & $\begin{array}{l}\text { Cenderung } \\
\text { rendah }\end{array}$ \\
\hline Role Restriction & $14.77(4.06)$ & $\begin{array}{l}\text { Cenderung } \\
\text { rendah }\end{array}$ \\
\hline Depression & $26.84(5.69)$ & Cenderung tinggi \\
\hline $\begin{array}{l}\text { Spouse/ parenting } \\
\text { partner relation- } \\
\text { ship }\end{array}$ & $13.26(4.92)$ & $\begin{array}{l}\text { Cenderung } \\
\text { rendah }\end{array}$ \\
\hline $\begin{array}{l}\text { Isolation } \\
\text { rend }\end{array}$ & $8.05(2.50)$ & $\begin{array}{l}\text { Cenderung } \\
\text { rendah }\end{array}$ \\
\hline Health & $82.21(11,51)$ & Tenderung \\
\hline $\begin{array}{l}\text { rendah } \\
\text { Mearenting Alliance }\end{array}$ & Tingi \\
\hline
\end{tabular}

Parenting alliance adalah kemampuan orang tua untuk bekerja sama satu sama lain untuk memenuhi kebutuhan anak (Abidin \& Konold, 1999). Tabel 2, menunjukan bahwa Ibu yang berada di lapas memiliki parenting alliance yang baik dengan pengasuh anak mereka. Hal ini berarti Ibu yang berada di lapas menghormati dan menghargai komitmen dan keputusan pengasuh anak, serta membentuk komunikasi dan kerjasama pengasuhan. Parenting alliance yang baik dapat memberikan orang tua sumber daya emosional dan psikologis untuk mengatasi parenting stress (Camisasca, Miragoli, \& Di Blasio, 2014).

Seperti terlihat pada Tabel 3, hasil perhitungan korelasi menunjukkan bahwa tidak terdapat hubungan yang signifikan antara parenting stress dengan parenting alliance pada Ibu yang menjadi WBP. Meskipun memiliki derajat parenting stress yang cenderung rendah dengan parenting alliance yang tinggi (Tabel 2). Hasil derajat parenting stress dan parenting alliance pada Ibu yang menjadi WBP berbeda dengan penelitian sebelumnya yang menunjukkan bahwa mereka memiliki parenting stress tinggi dan parenting alliance yang rendah (Loper et al., 2009). Komunikasi dan kerjasama yang baik dengan pengasuh dalan membuat Ibu yang menjadi WBP memiliki kontak dengan anak, sehingga berdampak Ibu memiliki hubungan yang positif dengan anak (Poehlmann, 2005). Hal ini juga dapat mendukung penilaian ibu bahwa mereka memiliki ikatan yang kuat dengan anak.

Tabel 3 Korelasi dengan Parenting Alliance Measure

\begin{tabular}{|c|c|}
\hline Variabel & Coefficient \\
\hline Parenting Stress Index &,- 102 \\
\hline
\end{tabular}

Salah satu dugaan yang dapat diajukan bahwa korelasi antara parenting stress dan parenting alliance yang tidak signifikan adalah bahwa Ibu yang menjadi WBP melihat positif diri mereka sebagai orang tua sehingga meminimalkan kondisi stres pengasuhan yang dirasakan. Selain itu, parenting stress dihasilkan dari jalur kognitif bahwa pemikiran dan interpretasi pada suatu peristiwa yang menyebabkan stress, bukan peristiwanya (Kennedy, 2012). Pada Ibu yang menjadi WBP, mereka memiliki pikiran dan keyakinan bahwa mereka dapat menjalankan peran sebagai orang tua. Sementara itu, parenting alliance, Ibu yang menjadi WBP menganggap bahwa ikatan dengan pengasuh anak tidak berkaitan dengan upaya pengasuhan yang dilakukan. Kedua asusmi tersebut perlu dilakukan riset untuk membuktikannya.

Terdapat beberapa keterbatasan dalam riset ini. Pertama, riset ini merupakan penelitian kuantitatif, sehingga tidak memiliki data yang mendalam seperti hasil interview mengenai gambaran parenting stress dan parenting alliance pada Ibu yang menjadi WBP. Kedua, riset ini hanya dilakukan pada satu Lapas Wanita, sehingga tidak dapat digeneralisasikan pada Ibu yang menjadi WBP di Lapas Wanita lainnya.

\section{SIMPULAN}

Ibu yang menjadi WBP memiliki tingkat parenting stress yang rendah dan parenting alliance yang tinggi. Parenting stress yang rendah dan parenting alliance pada Ibu yang menjadi WBP tidak memiliki korelasi 
yang signifikan. Ibu yang menjadi WBP memiliki level depression yang cenderung tinggi yang dapat diasumsikan bahwa Ibu yang menjadi WBP merasa bersalah karena terpisah dari anak mereka, tidak dapat mengasuh secara langsung, dan ketidakpuasan menjalani peran sebagai orang tua. Saran untuk riset selanjutnya adalah tidak hanya mengukur Ibu yang menjadi WBP, tapi juga mengukur parenting alliance pada pengasuh anak, serta bagaimana penyesuaian diri anak terhadap perpisahan dengan ibu karena pemenjaraan.

\section{DAFTAR PUSTAKA}

Abidin, R. R. (2012). Parenting stress index 4th edition. Lutz, FL: Psychological Assessment Resources.

Abidin, R. R., \& T.R. Konold. (1999). Parenting alliance measure professional manual. Lutz, FL: Psychological Assessment Resources

Amalia, Fadhilah. (2013). Studi Deskriptif Mengenai Derajat Stress dan Coping Stress pada Incarcerated Mother di Lembaga Pemasyarakatan Wanita Klas IIA Bandung. Skripsi, Program Studi Psikologi Fakultas Psikologi, Universitas Padjadjaran.

Camisasca, E., Miragoli, S., \& Di Blasio, P. (2014). Is the Relationship Between Marital Adjustment and Parenting Stress Mediated or Moderated by Parenting Alliance? Europe's Journal of Psychology, 10(2), 235-254. https://doi.org/10.5964/ ejop.v10i2.724

Deater-Deckard, Kirby. (2004). Parenting Stress: Current-Perspective in Psychology. Michigan: Yale University Press

Fogel, C. I. (1993). Hard T: the Stressful Nature of Incarceration for Women. Issues in Mental Health Nursing, 14(4), 367-377. https://doi. org/10.3109/01612849309006900

Griffith, Jayne., \& Andrew Steptoe. (2000). Prison. In Fink, George, Encyclopedia of Stress Vol. III (p. 241 - 246). San Diego: Academic Press

Houck, K. D. F., \& Loper, A. B. (2002). The relationship of parenting stress to adjustment among mothers in prison. American Journal of Orthopsychiatry, 72(4), 548-558. https://doi.org/10.1037/00029432.72.4.548

Kennedy, D. (2012). The Relationship between Parental Stress, Cognitive Distortions, and Child Psychopathology. Dissertation. Philadelphia College of Osteopathic Medicine.

Loper, A. B., Carlson, L. W., Levitt, L., \& Scheffel, K. (2009). Parenting stress, alliance, child contact, and adjustment of imprisoned mothers and fathers. Journal of Offender Rehabilitation, 48(6), 483-503. https://doi. org/10.1080/10509670903081300

Mumola, C. J. (2000). Incarcerated parents and their children. Retrieved from https://digitalcommons. law.ggu.edu/nij-ojp/29

Parke, R. D., \& Clarke-Stewart, K. A. (2002). Effects of Parental Incarceration on Young Children. "From Prison to Home" Conference. https://doi. org/10.1097/00006982-199515010-00032

Poehlmann, J. (2005). Incarcerated Mothers' Contact With Children, Perceived Family Relationships, and Depressive Symptoms. Journal of Family Psychology, 19(3), 350-357. https://doi. org/10.1037/0893-3200.19.3.350

Shaughnessy, J. J., Zechmeister, E. B., \& Zechmeister, J. S. (1990). Research methods in psychology, 9th e dition. New York: McGraw Hill.

Taylor, Shelley E., (2009). Health Psychology, 7th Edi- 